\title{
A Sexual Deviaton In Novel Kâmalaulya By Tulus Setiyadi (Sociological Review)
}

\author{
Nurnaningsih \\ \{n_nurnaningsih@ymail.com\} \\ Universitas Veteran Bangun Nusantara Sukoharjo
}

\begin{abstract}
Kamalaulya's novel tells about various sexual deviations that often occur in society. In this novel actually contains valuable life values. The aim of this research is to describe the sexual deviations in the Kamalaulya novel. This research is a descriptive qualitative research in the form of literary research. The data source is the Javanese Kamalaulya's novel. Data is the text of the Kamalaulya novel in the form of sexual deviations in the Kamalaulya novel. The results of the research mentioned that the Kamalaulya novel contains juvenile delinquency which leads to sexual deviation and is clearly depicted in literary works. In addition there is the attitude of male harassment towards a woman. The conclusion of this research is that the authors created literary works by taking incidents about sexual deviations in the community. The author also has a cultural attitude which is to teach the reader to always act right.
\end{abstract}

Keywords: literary sociology, sexual deviations, Javanese literature, Kamalaulya

\section{Introduction}

Literary works can be used to find out the human life. Literature is a form and result of creative art work whose object is human and his life uses language as the medium [1]. Literary work as a medium reflects the author's view of the various problems observed in his environment[2]. The author fully understands these problems, which are then expressed again through the means of fiction in accordance with his views[3].

Kamalaulya's novel is a story of young people who are close to free sex. This novel is about romance. The problem of love is a story that will not be finished because each individual has a different expression in reacting to it. This difference makes the problem of romance continue to grow throughout the ages. The social problem reflected in the Kamalaulya novel is actually an author's idea that wants to express the aspirations of the public regarding the rampant incidents of rape and sexual harassment among teenagers.

Therefore this novel would be very appropriate if studied in the sociology of literature. In the view of literary sociology that between literary works, authors, and society is something that can not be separated in the emergence of a literary work[4].

The difference between this research and previous research is in the study of Kamalaulya's novel with a sociological approach to literature, it will also be examined about social problems in the form of sexual deviations and moral education values that are revealed in literary works. One of the impacts of globalization is in the cultural aspects that different cultures are 
increasingly coming into contact with one another [5]. Based on the setting or setting in the story, lonely places can in fact invite immorality especially by young children. Tourist attractions are often used as nasty places for a number of young people [6].

\section{Research Method}

This research is a descriptive qualitative research in the form of literary research. Qualitative research is research that is natural in nature and produces descriptive data in the form of written or oral words from people, behavior, or other data that can be observed by researchers [7]. The data source is a Javanese novel by Tulus Setiyadi entitled Kamalaulya in 2019 by Pustaka Ilalang Lamongan, East Java. Primary data is the main data, in this study the structural elements in the Kamalaulya novel which include intrinsic elements of the novel, sexual deviations, the attitude of the author's culture and moral education values in the Kamalaulya novel. Data collection techniques using content analysis and interviews [8]. Interviews are conducted with questions that are open and lead to the depth of information.

Data analysis is the process of arranging data sequences. Data analysis aims to simplify data into forms that are easier to read and interpret [9]. In this research, the process of data analysis is carried out with the steps of data reduction, data presentation, and verification and conclusions.

\section{Results And Discussion}

Themes make the story more focused, integrated, conical, and impactful. The beginning and end of the story will be fitting, appropriate, and satisfying thanks to the existence of the theme. The theme is an element that is relevant to every event and the details of a story. The most effective way to recognize the theme of a work is to look closely at every conflict in it [10].,Kamalaulya's novel portrays characters such as Arman, Mirna, Suhardi, Fian, Fitri, Riyo, Ayshah. The teenage characters in the Kamalaulya novel are young people who eventually in their friendship they often carry out delinquents that lead to sexual. The setting takes place in the city of Ngawi, Ponorogo, East Java and its surroundings. The following data informs us that Fian and Fitri committed immoral acts when they rested in teak forests.

Mas, mas" karo njiwiti pupune Fian. Aja ngono, mengko menawa aku hmmm..malah hmmm.

Bocah loro banjur ngguyu cekikikan. Awit saka gemese Fitri ditarik lengene lan pipine diambungi. Rambute dielus-elus lan lambene wis mecaki ing gulu uga dhahane. Fitri mung bisa pasrah marang bocah lanang sing dadi geganthilane ati.

'Mas, mas, while pinching Fian's thigh. Don't be like that, later if I hmmm, and it can be hmmm. Two people then laughed loudly. Because Fitri passionately then pulled his arm and admired his cheek. Hair stroked and lips have clung to the neck and chest. Fitri is only resigned to the boy who becomes his idol. '

In the data it can be seen that young people today when in tourist attractions, places that are quiet and far from parents are often not controlled by their actions. This can be seen in the novel that Fian and Fitri committed acts of sexual deviation that were actually not feasible. Authors' concerns about various social phenomena that occur in society inspire the author of 
Kamalaulya nouvel. Tulus Setiyadi feels called and must help improve the morale of the younger generation in the current era. Social problems regarding juvenile delinquency, sexual acts outside of marriage become a hot theme that is often written by Tulus Setiyadi.

Ing tengah alas kuwi, bocah loro mung ngumbar marang napsune. Angin kang sumilir meh ngombyongi anggone bocah loro andum katresnan. Dumadakan Fitri njerit awit ana sing ngganjel lan krasa perih. Nanging sangsaya suwe malah mangap-mangap ngrasakake kepenak.

'In the middle of the forest, the two children vent their lust. The wind that blew was like accompanying the two children who shared their love. Suddenly Fitri screamed because of the lumps and pain. But after a long time looked comfortable and felt a sense of pleasure.

Sexual deviations that are often done by teenagers are interesting to be reviewed with a sociological approach to literature. Tulus Setiyadi with the style of composure of an author is able to present his characters as if alive and able to move the storyline. This is seen in the data as follows.

Karo ngelus-elus wetenge, Ayshah nangis sesenggrukan. "hahh..yo jebul kwoe apus karma.."pangudarasane. Ayshah nalika tetangisan ing njero kamar. Sawetara panyawange terus tumuju wetenge. Ing kono sinimpen bibite Riyo awit saka anggone wani nerak marang wewaler.

'While stroking her stomach, Ayshah burst into tears. "Hahh. It turns out you're just cheating .." he thought when crying in the room. While his eyes were only on his stomach. Riyo's seeds were stored there because they dared to break the ban '.

The text above is one of the behaviors that deviates from religious values because Ayshah and Riyo have sex that should not be carried out before being officially married. Ayshah and Riyo's actions are acts that violate religious norms.

The actions depicted in the Kamalaulya novel are very alarming. Promiscuity is one of the characteristics that is not true in the sense of modern association. Incorrect understanding of modern relationships is something that is rah-rah, full of freedom, not normed, and similar behavior in life related to sexual behavior. Sexuality is not only sexual behavior, especially free sex, but an activity that has spiritual and physical / biological benefits.

Promiscuity is not only measured by modernity in which there are no norms in society, but there must be a modern social concept that is in accordance with the mindset of the times that follows the norms in society.

Human sexuality is the result of social construction. A person's sexual expressions cannot be separated from the socio-cultural norms that apply in society. If separated from the sociocultural norms is a deviation from the values that exist in society, including moral values, religious values, social values, the value of struggle, the value of heroism, and didactic values.

Riyo violated moral values because she was not responsible for what she did to Ayshah and she always lied to her boyfriend. Riyo's no responsibility and lies to Ayshah are deviations from moral values.

The text above is also Ayshah's struggle to get responsibility from Riyo because he had sex with her and became pregnant. Actually Riyo's actions with Ayshah also violated religious and moral norms.

Other sexual deviations namely Arman always has the desire to obey his lust to Fitri. Sexual texts in the Kamalaulya novel actually violate the value of education because the behavior carried out by Fitri, Mirna, Ayshah does not educate the nation's generation. The 
actions of dominant figures deviate from religious, moral, social, religious values and norms, friendship, struggle, and didactic values.

The figure in the Kamalaulya novel who behaves sexually aberrant is as follows. Fitri (student) with Fian (student). Fitri (student) with Arman (student). Fitri (student) with Ari (Ariyo Bima). Ayshah with Riyo (Ariyo Bima). Ayshah with Riziq. Mirna (SMK alumni) with Mr. Suhardi (father of Ariyo Bima), and Mrs. Sunarti with Mr. Suhardi.

The moral education values in Kamalaulya's novel illustrate the life side of Fitri and Ayshah. Ayshah as a woman living in modern times realized that Riyo was an irresponsible man.

There is a negative side to this seen in the Kamalaulya novel, namely the desire to gain freedom in fulfilling biological needs in its own way. Free sex by men who are either closed or openly get opposition from various parties. Moreover, women who have been known to have feelings of shame that are big enough can do so.

There is an attempt to justify Tulus Setiyadi on the deviations made by male figures and wants to defend what is experienced by women. But the defense itself is actually a reflection of the shame of acknowledging that the character's actions are indeed not true, herein lies the uniqueness.

Another thing that shows the negative side of this novel is the fact that it is indeed difficult to deny, sometimes women who are concerned with their own world and are too resigned to friends or spouses. Fian and Fino take advantage of women's weaknesses.

The final step in this research is to observe the attitude of the authors of the works being studied. Here we will analyze Tulus Setiaydi's attitude as the author of the Kamalaulya novel. The analysis in this discussion is the tone or atmosphere that Sincere presents in his work. The tone or atmosphere of the story in general is able to express the intent of the author in presenting characters who will be opposed or supported by feminists.

In this novel, Tulus Setiyadi seems to want to convey his views and ideas seriously and frankly. Through the figure of Ayshah and Fitri it was revealed that the author actually always encouraged women to learn about life first before marriage. Women are encouraged to obtain the highest possible knowledge so that they are not easily fooled by others.

Fitri and Ayshah figures show how important a woman's personality maturity is. Armed with a good personality, women can choose what is good and what is not good. Although she is a woman who comes from the village, but she must have the knowledge or personality like young people who have received education in college.

Another attitude of the author's culture is the increase in divorce rates and the increasing number of women who are abused, and choose to live as a single parent. This also happened to the figure of Fitri and Ayshah, he deliberately had an intimate relationship with his girlfriend. Fitri has bitter memories with Fino and reminds him of the man who tricked him.

Free sex by men who are either closed or openly gets opposition from various parties, especially with women who have been known to have considerable feelings of shame. Even though Fino and Fitri love each other but because the bond is not yet official, the relationship between the two is a relationship forbidden. Fitri was actually very aware of this, but he could not deny the urge to always be one with Fino. When they meet they often spend time as husband and wife, even in the Kamalaulya novel also described if Fino did not start, sometimes Fitri who can not maintain his attitude.

Free sex is not a good action, but women must have control both in their mindset and mastery over their own bodies. This also happened to the figure of Fitri, he deliberately had an intimate relationship with Fino. 
Various studies that show that the environment influences the way of thinking and the way of thinking of a person appear in Nor Hashima Hashim's research[12]. Products from the environment affect one's attitude to action. The location and social conditions around him are factors that greatly influence one's actions[11]. In the novel Kamalaulya is told because of promiscuity, the role of parents is minimal, and the strategic and lonely location to be able to act unkind is a trigger for immoral acts, acts of sexual harassment, and so on.

Traditional and modern societies in Febriani's research also have a different mindset. Traditional society and less education are more accepting of what it is, surrender to everything experienced. Modern society tends to be aggressive, not giving up easily. Sometimes more modern societies often take advantage of a class of people who are less educated [13]. In the novel it is stated that Fitri is actually an innocent girl and trusts her lover if her boyfriend asks to have sex. Fino in the novel is told to take the opportunity of Fitri's innocence.

In Javanese culture, the situation of relations between social roles among the participants plays a crucial role in determining the choice of speech acts and politeness strategies. If the speaker has a higher social status, but at the same time still wishes to show respect for the hearer of lower social status, the speaker can directly change the choice of speech acts and politeness strategies [14].The author explains that the role of literary work is basically a communication system that conveys its message not primarily in abstract terms but in the building of images, a concrete imaginary world [15] [16]. Thus the research of literature by linking external factors, namely the author, the socio-cultural conditions underlying the novel to emerge, need to be included.

\section{Conclusion}

Literature as a manifestation of phenomena that are outside of literary works. The existence of the author is inseparable from the events that occur in the community. The relationship between authors, literary works, and society. The author is a member of the community often writing literary works inspired by various phenomena that occur in society. The things written in literary works are largely a reflection of events in society. Thus a close relationship exists between the author and the community.

Kamalaulya by Tulus Setiyadi's are descriptions of events raised in his work. Infidelity, sexual harassment, juvenile delinquency dominates the story in this novel. As if, juvenile delinquency which leads to sexual deviation is depicted clearly in literary works. Thus it is very interesting to discuss why the author creates such works, what cultural attitudes lie behind the authors so as to create this Kamalaulya work.

In the context of face-to-face communication, harmonious social relations can be realized if the participants respect and avoid being condescending to each other. An atmosphere of such mutual respect and not being condescending toward others in communicative situations can be created if both parties prioritize joint agreement and a sympathetic attitude. In the Kamalaulya novel also told that in addition to a comfortable and quiet place can invite disobedience, also influenced by a person's speaking style. Fino was able to convince Fitri that after intercourse she wanted to marry him. But in fact Fino did not keep promises. Kamalauya, yes actually is a portrait of life in modern times that implicitly always reminds us / readers not to engage in sexual behavior that deviates from social aspects such as moral values, religion, and so on. 


\section{References}

[1] Atar Semi. Metode Penelitian Sastra. Bandung: Angkasa, 1990.

[2] Sugihastuti dan Itsna Hadi Saptiawan. Gender dan Inferioritas Perempuan: Praktik Kritik Sastra Feminis. Yogyakarta: Pustaka Pelajar, 2007.

[3] Burhan Nurgiyantoro. Teori Pengkajian Fiksi. Yogyakarta: Gadjah Mada University Press, 2005.

[4] Nyoman Kutha Ratna. Sosiologi Sastra. Yogyakarta: Pustaka Pelajar, 2013.

[5] Suseela Devi Chandran, "Strengthening People-to-People (P2P) Connectivity through Cultural Exchange: Malaysia-India Bilateral Relations in a Globalised World”, Jurnal Pertanika J. Soc. Sci \& Hum. 25 (S): 29-40.

[6] Umi Thoifah Amalia, Endang Purwaningsih, "Local Wisdom Tourism Development Of Semarang With Tourism Cluster System As An Action For Sustainble Economics Development", Prosiding seminar internasional ELIC 2017, The 1st Education and Language International Conference, Proceedings Center for International Language Development of Unissula, 2017.

[7] Sangidu. Penelitian Sastra: Pendekatan, Teori, Metode, Teknik, dan Kiat. Yogyakarta: Unit Penerbitan Sastra Asia Barat UGM, 2004.

[8] Beni Ahmad Saebani. Metode Penelitian. Bandung: Pustaka Setia, 2008.

[9] Lexy J. Moleong. Metodologi Penelitian Kualitatif. Bandung: Remaja Rosdakarya, 2010.

[10] Robert Stanton. Teori Fiksi Robert Stanton. Yogyakarta: Pustaka Pelajar, 2007.

[11] Jane C. Ollenburger dan Helen A. Moore. 1996. Sosiologi Wanita. Jakarta: PT. Rineka Cipta, 1996.

[12] Nor Hashima Hashim, Nur Amirah Mamat, Najihah Nasarudin and Nur Anisah Ab Halim, "Coffee Culture among Generation Y", Jurnal Pertanika J. Soc. Sci. \& Hum. 25 (S): 39 - 48 (2017).

[13] Febriani Elfida Trihtarani, "The Clash of Traditional and Modern Cultures in the Novels Samdae (Three Generations) by Yeom Sang Seop and Tetralogi Buru (Buru Quartet) by Pramoedya Ananta Toer”, Jurnal Humaniora Vol. 31, No. 2 (June 2019).

[14] Dwi Rahmawanto \& F.X. Rahyono, "Strategies for Establishing Harmony in Javanese Face-toface Dialog in Purwa Shadow Puppet Performances" Jurnal 3L: The Southeast Asian Journal of English Language Studies - Vol 25(1): 115 - 128, 2019.

[15] Wiewien Rahayu, "Nasionalisme Puitis: Sastra, Politik, dan Kajian Budaya'. Jurnal Humaniora Vol. 30 Number 3 October 2018.

[16] K. Saddhono and M. Rohmadi, "A Sociolinguistics Study on the Use of the Javanese Language in the Learning Process in Primary Schools in Surakarta, Central Java, Indonesia." Int. Edu. Stu., vol. 7 no. 6 pp 25-30, 2014 